\title{
GUIDE TO TREATMENT TECHNOLOGY FOR CONTAMINATED SOILS (U)
}

by $H$. Tran

Westinghouse Savannah River Company

Savannah River Site

Aiken, South Carolina 29808

Other Authors:

R. Aylward

(WSRC)

This paper was prepared in connection with work done under Contract No. DE-AC09-89SR18035 with the U. S. Department of Energy. By acceptance of this paper, the publisher and/or recipient acknowledges the U. S. Government's right to retain a nonexclusive, royalty-free license in and to any copyright covering this paper, along with the right to reproduce and to authorize others to reproduce all or part of the copyrighted paper.

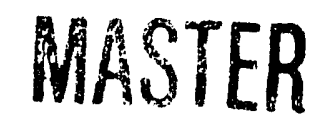




\section{DISCLAIMER}

This report was prepared as an account of work sponsored by an agency of the United States Government. Neither the United States Government nor any agency thereof, nor any of their employees, makes any warranty, express or implied, or assumes any legal liability or responsibility for the accuracy, completeness, or usefulness of any information, apparatus, product, or process disclosed, or represents that its use would not infringe privately owned rights. Reference herein to any specific commercial product, process, or service by trade name, trademark, manufacturer, or otherwise does not necessarily constitute or imply its endorsement, recommendation, or favoring by the United States Government or any agency thereof. The views and opinions of authors expressed herein do not necessarily state or reflect those of the United States Government or any agency thereof.

This report has been reproduced directly from the best available copy.

Available to DOE and DOE contractors from the Office of Scientific and Technical Information, P.O. Box 62, Oak Ridge, TN 37831; prices available from (615) 576-8401, FTS 626-8401.

Available to the public from the National Technical Information Service, U.S. Department of Commerce, 5285 Port Royal Rd., Springfield, VA 22161. 


\section{\#งñc-iM-32:27}

\section{GUIDE TO \\ TREATMENT TECHNOLOGY FOR CONTAMINATED SOILS}

August 4,1992

Westinghouse Savannah River Company Savannah River Site Aiken, SC 29808 
THIS DOCUMENT WRS PREPARED BY ASSESSMENTS

ENGINEERING FOR USE IN THE DEUELOPMENT OF FEASIBILITY STUDIES FOR ENUIRONMENTAL RESTORATION WASTE SITES.

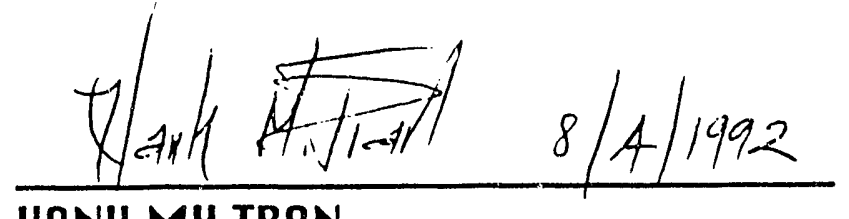

HANH MY TRAN

fssessments Engineering

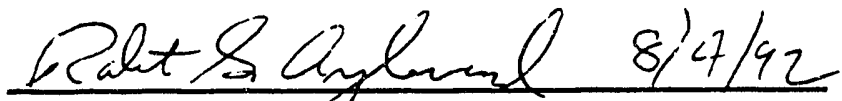

ROBERT S. AYLUURRD

Manager, Assessments Engineering

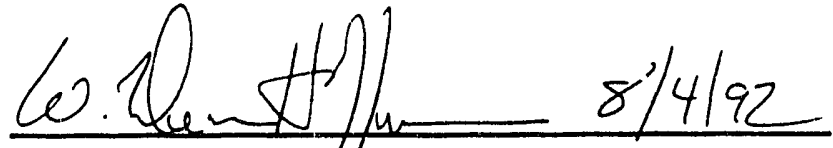

W. DEAN HOFFMAN

Manager, Assessments 


\section{GUIDE TO \\ TREATMENT TECHNOLOGY FOR \\ CONTAMINATED SOILS}

Pugust 4,1992

Westinghouse Savannah River Company

Savannah River Site

Aiken, SC 29808 


\section{TABLE OF CONTENTS}

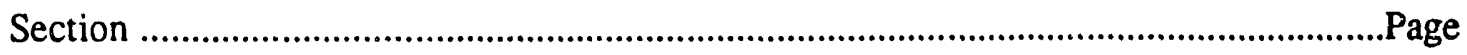

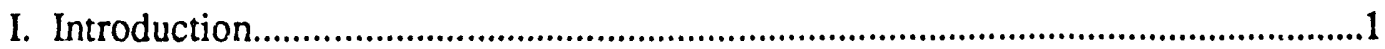

II. Utilizing The Tables..............................................................................................8

III. Tables: Contamination Versus Technology.............................................................9

A. Biological Treatment Technologies.............................................................10

Aerobic Biodegradation

1. Slurry -Phase Biodegradation...............................................................10

2. Composting.........................................................................................10

3. Solid-Phase Biodegradation..................................................................10

4. In-Situ Biodegradation......................................................................10

5. Fluid Extraction Biodegradation......................................................10

6. Biogenesis Soil Cleaning Process..........................................................10

7. Bioscrubbers.......................................................................................10

8. Geolock/Bio-Drain Treatment Platform............................................10

9. Photolytic/Biological Soil Detoxification...............................................10

Anaerobic Biodegradation..................................................................................10

B. Solidification / Stabilization Treatment..........................................................11 Cement-Based Fixation

1. In-Situ Soil Stabilization.....................................................................11

2. Silicate-Based Solidification..............................................................11

3. In-Situ Soil Mixing............................................................................11

Pozzolanic-Based Fixation

4. Solidification/Stabilization (Hazcon)................................................11

5. Soilidification/Stabilization (Wastech)..............................................11

Vitrification

6. In-Situ Vitrification.......................................................................11

C. Thermal Treatment Technologies....................................................................12

Fluidized Bed

1. Circulating Bed Combustor............................................................12

2. Desorption \& Vapor Extraction System..............................................12

Flame Combustion

3. Pyretron Oxygen Burner....................................................................12

4. Flame Reactor...........................................................................12

5. Cyclone Furnace..........................................................................12 
Infrared Incineration

6. Electric Infrared Incineration............................................................12

7. Radio Frequency Thermal Heating....................................................12

Plasma System

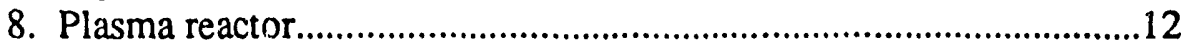

Thermal Incineration

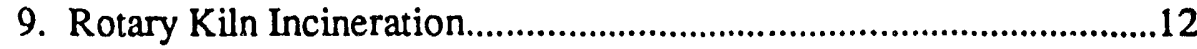

10. Pyrokiln Thermal Encapsulation.................................................12

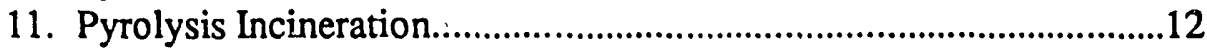

D. Chemical / Physical Treatment Technologies.................................................13

Evaporation \& Steam Stripping

1. In-Situ Vacuum \& Steam extraction...............................................13

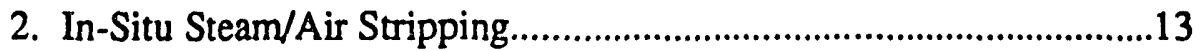

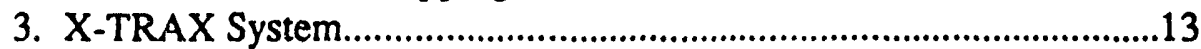

Solvent Extraction

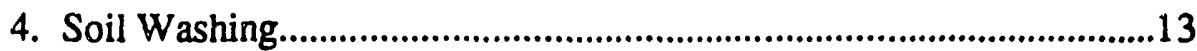

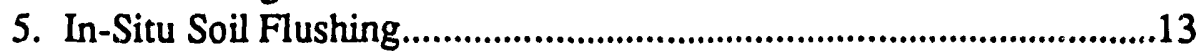

6. Solvent Extraction (BEST) ...........................................................13

7. Carver Greenfield Extraction Process.................................................13

8. Solvent Extraction (CF)...............................................................13

9. Glycolate Dechlorination..............................................................13

Electrokinetics

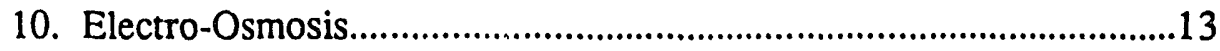

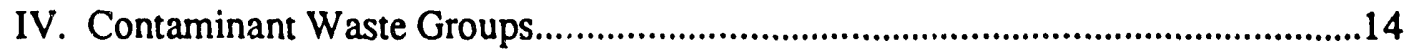

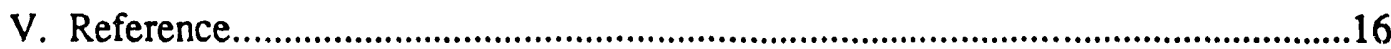




\section{: INTRODUCT!ON}

This document is a guide for the screening of alternative treatment technologies for contaminated soils. The contents of this guide are organized into: I. Introduction, II. Utilizing the table, III. Tables: Contamination Versus Technology, IV. Contaminant Waste Groups, and V. References.

The four Contaminations Versus Technology tables are designed to identify the effectiveness and/or potential applicability of technologies to some or all compounds within specific waste groups. The tables also present limitations and special use considerations for the particular treatment technology. The phase of development of the technology is also included in the table. The phases are: Available, Innovative, and Emerging technologies.

The technologies presented in this guide are organized according to the method of treatment. The four (4) treatment methods are Biological, Solidification/Stabilization, Thermal, and Chemical/Physical Treatment. There are several processing methods; some are well developed and proven, and others are in the development stage. The processing modes described herein are:

A. BIOLOGICAL TREATMENT (Table A) : A treatment process in which bacteria, fungi, and/or microorganisms are used to destroy hazardous waste. Compounds that could possibly be treated in this manner include aliphatics, aromatics, and chlorinated aromatic organic compounds. The process is highly sensitive to environmental conditions, including fluctuations in $\mathrm{pH}$ and temperature, and to changes in the concentrations of heavy metals and salts in the waste stream.

Biological treatment includes 2 processes and a series of technologies fall under each process:

Aerobic Biodegradation Process involves the treatment of contaminated soil in a large mobile hioreactor. An aqueous slurry is created and then is mechanically agitated in a reactor vessel to keep the solids suspended and maintain the appropriate environmental conditions. Once biodegradation of the contaminants is completed, residual water may require further treatment before disposal, and emissions may be released to the atmosphere or treated prior to release. Some of the advantages of using a bioreactor include:

- Greater process management and control. Increased contact between

microorganisms and contaminants.

- Use of specific cultures or inoculum.

- Decreased acclimation times and faster biodegradation rates.

One disadvantage is the additional excavation and handling of the contaminated material that is often required.

* 1. Slurry-Phase Biodegradation: A technology in which organic materials and water are placed in a high energy environment. The waste then undergoes aerobicbiological treatment in a batch digester and is transferred to a polishing cell for final treatment.

* 2. Composting: This technology involves the storage of large volumes of highly biodegradable and structurally firm material with a small percentage of 
hindegradable waste. There are three basic types: static windrow system, open windrow system, and in-vessel (reactor) system.

* 3. Solid-Phase Biodegradation: This process treats soils in an above grade system using conventional soil management practices to enhance the microbial degradation of contaminants. The system was designed to contain and treat soil leachate and volatile organic compounds.

* 4. In-situ Biodegradation: This technology uses or introduces aerobic or anaerobic bacteria to biodegrade organic compounds in soils. It involves enhancing the natural biodegradation process by injecting nutrients (i.e., phosphorus, nitrogen, etc.), oxygen, and cultured bacterial strains.

* 5. Fluid Extraction-Biological Degradation: A technology which utilizes three process steps: 1) fluid extraction, which removes organics from soils, 2) separation, which transfers pollutants from an extract to a biological treatment system. 3) biological treatment, which degrades organic pollutants to innocuous products.

* 6. Biogenesis Soil Cleaning Process: This technology uses a specialized truck, gravity and cyclone separators, and a bioreactor to wash contaminated soil.

* 7. Bioscrubbers: This technology digests hazardous organic emissions from soil. It contains Alcoa's activated carbon medium as a support for microbial growth.

* 8. Geolock/Bio-Drain Treatment Platform: This technology utilizes a bioremediation system that is installed in the soil or waste-matrix, and can be adapted to the soil characteristics of the area, the concentration of the contaminants, and the geologic formation. The system is composed of an in-situ tank, an application system, and a bottom water recovery system.

* 9. Photolytic/Biological Soil Detoxification: This technology is effective for shallow soil contamination. The system consists of two (2) step processes: 1) Degrade the organic contaminants using ultraviolet (UV) radiation, 2) Destroy the organic contamination and detoxify the soil using biological degradation.

Anaerobic Biodegradation: This technology involves the bioremediation of soils and sludges contaminated with Nitroaromatics. Anaerobic microbial mixtures have been developed for the pesticide dinoseb and for TNT.

B. SOLIDIFICATION/STABILIZATION TREATMENT (Table B) : This treatment process isolates hazardous wastes from the surrounding environment without destroying the hazardous constituents. Solidification / Stabilization processes have two key components: the chemical reactants and the mixing equipment. The chemicals typically include portland cement, lime, fly ash, clay, silicates, and a proprietary chemical. The proprietary chemical reacts with the metals and organics to form insoluble compounds and prevents the organic constituents from interfering with the pozzolanic (cement) reactions. Effective mixing is required whether the waste and the chemicals are mixed in-situ or above ground in tanks, drums, or pits.

Solidification /Stabilization includes three (3) processes and a series of technologies fall under each process:

Cement-Based Fixation Process treats sludges and soils containing metal cations, radioactive wastes and solid organic wastes by the addition of large amounts of siliceous materials combined with cement to form a dewatered, stabilized, solidified product. Soluble silicates are added to accelerate hardening of a containment. 
*1, In-Situ Soil Stabilization System: I'h1s technology immobiiizes urganic and inorganic compounds in wet or dry soils, using reagents (additives) to produce a cement-like mass. This process employs a proprietary binding agent for use with cement and a specific soil mixing technology which precludes the need for soil excavation.

*2. Silicate-based Solidification: This technology uses silicate compounds and can be used as two separate technologies-one that fixes and solidifies organics and inorganics contained in contaminated soils and sludges, and the other removes organics from contaminated water.

*3. In-Situ Soil Mixing: This technology uses multi-axis, overlapping hollow stem augers to inject and blend treatment additives, such as Solidification/Stabilization agents. The system can treat 90 to 140 cubic yards in-situ per eight-hour shift at depths of up to 100 feet.

Pozzolanic-Based Fixation process treats sludges and soils containing heavy metals, waste oils, solvents, and low-level radioactive wastes, onsite by the addition of large amounts of pozzolanic materials (fly ash, lime) combined with cement to form a dewatered stabilized, solidified product.

*4. Solidification/Stabilization (Hazcon): This technology immobilizes the contaminants in soils by binding them into a concrete-like, leach-resistant mass. The unit consists of soil and cement holding bins, a Chloranan feed tank, and a blending auger to mix the waste and pozzolanic materials.

*5. Solidification/Stabilization (Wastech.): This technology uses proprietary surfactants (detergent) to segregate organic pollutants into micelles before mixing the waste with proprietary bonding agents and pozzolanic and cementation material. The materials handling system consists of standard equipment such as a pug mill mixer cement truck, a cement batcher, and a cement pump.

Vitrification Process uses very high temperature to convert hazardous wastes into a glassy substance. It is carried out by inserting large electrodes into contaminated soils containing significant levels of silicates.

*6. In-Situ Vitrification: This technology destroys organic pollutants in soils and sludges by pyrolysis; inorganic pollutants are immobilized within the vitrified mass. The basic configuration of the ISV process consists of an electrical network with four (4) electrodes driven/pushed into the soil or placed in drilled holes and a capture hood to collect fumes or gases from the setting and direct it to an off-gas treatment system.

C. THERMAL TREATMENT (Table C): This treatment process uses energy to destroy or decontaminate waste. These technologies can either use low temperature or high temperature thermal processes. Low temperature thermal processes physically separate organic contamination from solid waste using elevated $(300-700 \mathrm{~F})$ temperature. Because of the low temperature, the organic contamination is volatilized from the solid waste but is not oxidized. Instead, it is burned in an after-burner or captured on a carbon bed.

Low temperature thermal processes are most effective on soils contaminated with organic wastes having relatively low boiling points. Low temperature thermal treatment processes usually have lower operating costs than other thermal technologies due to lower energy requirements.

High temperature thermal treatment technologies use combustion temperatures in excess of $1650 \mathrm{~F}$ to destroy or detoxify hazardous wastes. Organic chemical wastes are destroyed by the high temperatures. 
Thertial troatmcni includes five (5) processes and a series of technologies fall under each process:

Fluidized bed combustors are used to incinerate halogenated and nonhalogenated solids, sludges, slurries, and liquids in a controlled atmosphere with surplus oxygen levels. These systems are used to destroy polychlorinated biphenyls (PCBs) and phenolic wastes and to thermally decontaminate soils. In this process a hot fluidized bed of inert granular material is used to transfer heat to the waste streams to be incinerated. Combustion takes place as the waste contacts the hot fluidized bed. Ash will normally exit the fluid bed reactor airborne in the flue gas. The advantages of the fluidized bed design are the relatively low excess air requirements, and good mixing between air and fuel.

*1. Circulating Bed Combustor $(C B C)$ : This technology destroys a variety of waste materials at relatively low Temperature (approx. 1600 F). It uses simultaneous limestone injection, which neutralizes acid gases and eliminates the need for a scrubber. Waste material and limestone are fed into a combustion chamber along with recirculating bed material from a hot cyclone. The materials travel at high speed through the combustion chamber to the cyclone, where the solids are separated from the hot gases. The hot gases pass through a convective cooler and bag house filter before being released to the atmosphere. The treated ash is transported out of the system by an ash conveyor for proper disposal.

*2. Desorption \& Vapor Extraction System: This technology uses a low temperature fluidized bed to remove organic and volatile inorganic compounds from contaminated wastes (soils, sediments, \& sludges), which are mixed with hot gas (at about $320 \mathrm{~F}$ ) in a co-current, stirred fluidized bed. The heated air, vaporized water and organics, and entrained particles flow out of the dryer to a gas treatment system, which consists of a cyclone separator, bag house, venturi scrubber, plate scrubber, and chiller unit.

Flame combustion Process refers to combustion which takes place in or as the result of a hydrocarbon flame. Hydrocarbon flames result from the oxidation of hydrocarbon fuels with air, oxygen, or oxygen-enriched air. The advantage of the flame combustion process is the short residence time which allows for high waste throughput. Hazardous wastes treated with flame combustion are readily converted to carbon dioxide and water.

*3. Pyretron Oxygen Burner: This technology involves an oxygen-air-fuel burner, and uses advanced fuel injection and mixing concepts to burn wastes at higher temperatures. The bumer operation is computer-controlled to automatically adjust the amount of oxygen for sudden changes in the heating value of the waste. The burner is designed to fit onto any conventional combustion unit.

*4. Flame Reactor: This reactor processes wastes with a very hot (greater than $2000 \mathrm{C}$ ) reducing gas produced from the combustion of solid or gaseous hydrocarbon fuels in oxygen-enriched air. The system is operated to produce a decontaminated molten slag (a glasslike solid when cooled) and a recyclable, heavy metal-enriched oxide.

*5. Cyclone Furnace: This technology is designed to achieve very high heat release rates and temperatures by swirling the incoming combustion air while retaining heavy metals in a nonleachable slag, vaporizing and incinerating the organic materials in the wastes.

Infrared Incineration Process uses silicon carbide elements to generate intense thermal radiation. Other thermal processes use turbulent air flows. In this process, materials to be treated pass through the combustion chamber on a conveyor belt and 
are exnnced to the radiation. This reduces the amount of ash in the air stream since, without turbulent air flows, the ashes fall from the belt to the ash collector. Infrared incineration provides an airtight operation which allows the thermal destruction of low-level radioactive materials.

*6. Electric Infrared Incineration: This technology is a mobile thermal processing system that uses electrically-powered silicon carbide rods to heat organic wastes to combustion temperatures. One configuration for this mobile system comprises four components: an electric-powered infrared primary chamber, a gas fired secondary combustion chamber, an emission control system, and a control center.

*7. Radio Frequency Thermal Heating: This technology uses electromagnetic energy applied in the radio frequency band to heat large volumes of soil, thereby encouraging the volatilization of contaminants. The process is similar to that of a microwave oven, except that the heated volumes are larger and the frequency of operation is different. As a result, the soil is heated primarily by molecular agitation, rather than thermal conduction. The energy may be applied to the soil either through electrodes which are distributed horizontally to the contaminated area, or through a vertical electrode array which is inserted in the soil. Four subsystems are required for an in-situ RF Heating System are: electrode array, RF power generation and control system, vapor containment, and vapor treatment and handling.

Plasma System processes decontaminate waste by contacting it with a gas which has been energized into its plasma state by an electrical discharge. Plasmas contain very high energy. Waste organic chemicals injected directly into a plasma plume are fragmented and converted to carbon dioxide and water. Solid waste heated by plasma can be vitrified.

*8. Plasma Reactor: This thermal treatment centrifugal reactor uses plasma heat to create a molten bath, which detoxifies contaminants in wastes. The solid components are melted (vitrified) and cast or granulated for disposal, while the volatile compounds are decomposed by the heat generated by the plasma.

Thermal incineration process involves the controlled combustion of organic wastes under net oxidizing conditions.

*9. Rotary Kiln Incineration: This technology controls combustion of organic wastes under net oxidizing conditions in slightly inclined, refractory lined cylinders.

*10. Pyrokiln Thermal Encapsulation: This technology improves conventional rotary kiln hazardous waste incineration by introducing inorganic additives with the wastes to promote incipient slagging or "thermal encapsulating" reactions near the kiln discharge end.

*11. Pyrolysis Incineration: This technology uses high temperature to destroy organic material in the absence of oxygen to reduce toxic organic constituents to elemental gas and water.

D. PHYSICAL/CHEMICAL TREATMENT (Table D): :hysical treatment process separates the soil contaminants by either applying physical force or changing the physical form of the waste. Various physical processes, such as evaporation and steam stripping, extraction, and mechanical screening can be used to separate hazardous wastes. Physical treatment is applicable to a wide variety of wastes, but further treatment, usually incineration, is usually required.

Chemical treatment process changes the chemical structure of the constituents to produce a 
waste residue that is less hazardnus than the original waste. One lumutung tactor is that impurities and mixed waste components may interfere with the process chemical reaction and impact the reatment efficiency or produce hazardous by-products.

Physical/chemical treatment includes three (3) processes and a series of technologies fall under each process:

Evaporation and Steam Stripping process: Evaporation is the physical separation of a liquid from a dissolved or suspended solid by the application of energy to volatilize the liquid. Volatile organic compounds can be removed by phase changes. This $\mathrm{zan}$ be achieved by speeding the vaporization process which releases the volatile compound's into the carrier gas stream for removal and detoxification. In hazardous waste treatment, evaporation may be use to isolate the hazardous material in one of the two phases.

The operation of steam stripping uses steam to evaporate volatile organics from wastes. Steam stripping is simnly a continuous fractional distillation process carried out in a packed or tray tower.

*1. In-Situ Vacuum \& Steam Extraction: This technology is the process of removing and treating contaminated wastes from the vaduse or unsaturated zone of soils. The basic components include: Extraction and monitoring well(s), manifold piping, vapor/liquid separator, vacuum pump, and emission control equipment, such as activated carbon canisters. For a steam extraction, a similar system involves a series of air injection and air extraction wells.

*2. In-Situ Steam/Air Stripping: This technology uses a transportable "detoxifier" treatment unit which consists of two main components: the process tower and process train. The transportable unit uses drills that have been modified to allow for the expulsion of steam and air through the cutting blades. First, the soil is made permeable by the blades on the drills. Then the steam and air are injected to strip the contaminants and carry them to the surface. A metal box covers the treatment area to trap and transport the stripped volatiles to the treatment trailer. The water and organics in the gases are condensed, then separated and recovered.

*3. X-TRAX Low Temperature Thermal Desorption: This technology is a low temperature $(200-900 \mathrm{~F})$ thermal separation process. It is not an incinerator or a pyrolysir s,y: $\mathrm{rm}$. The system uses a process in which solids with organic contaminatiun are heated in the presence of wat.r, driving off the water and organic contaminants and producing a dry solid containing trace amounts of the organic residue. X-TRAX system consists of a dryer and an off-gas handling trailer.

Solvent Extraction process is based on the solubility of the hazardous chemicals in various solvents to perform the physical separation process. When a waste stream contacts with the particular solvent, hazardous materials dissolve as solute and are removed from the waste stream. After separating the solvent and solute from the waste stream, further treatment can be performed to detoxify these hazardous materials.

*4. Soil Washing: This system consists of a soil washer, a slurry bioreactor, and a fixed-film bioreactur. The soil washer uses water in a multi-staged series of intensive scrubbing to separate the heavily coniaminated fine fraction of the soil from the coarser to less contaminated sand fraction.

*5. In-Situ Soil Flushing: This technology is a process applied to unexcavated soils using a ground water extraction/reinjection system. The system includes extraction wells drilled in the contaminated soils zone, reinjection wells upgradient of the contaminated area, and a wastewater treatment system. 
*6. Solyon! Ertraction (Basic Extraction Sludge I'reatment (B̈EST)):

This technology is a mobile solvent extraction system that uses one or more secondary or tertiary amines (usually triethylamine (TEA)) to separate hydrocarbons from contaminated wastes.

*7. Carver-Greenfield Extraction Process: This technology removes various oil-soluble hazardous organic contaminants (hydrocarbons and chlorinated hydrocarbons) by extraction into food-grade oil.

*8. Solvent Extraction $(C F)$ : This technology uses vapor recompression and conventional distillation to recycle the solvents and concentrate the organic constituents.

*9. Glycolate Dechlorination: Potassium polyethylene glycolate (KPEG) dechlorination is used to dehalogenate certain classes of chorinated organics. The KPEG solution reacts with the chlorinated organic and displaces a chlorine molecule. The process involves mixing equal amounts of contaminated soil and KPEG reactants in a heated reactor.

Electrokinetics process is an in-situ separation/removal technique for extracting heayy metals and/or organic contaminants from soils. Studies of the electrochemistry associated with the process indicate that an acid front is generated at the anode. In time, this acid front migrates from the anode towards the cathode. Movement of the acid front by migration and advection results in desorption of contaminants from the soil. This phenomena provides an advantage over pumping techniques for in-situ treatment of contaminated fine-grained soils.

*10. Electro-Osmosis $(E O)$ : The technology uses electricity to affect chemical concentrations and ground water flow. In electro-osmosis (EO), the fluid between the soil particles moves because a constant, low DC current is applied through electrodes inserted into a soil mass. The efficiency of electro-osmotic water transport under $E O$ varies with the type of soil. 


\section{IIT!IIZING THE TABLES}

To use this guide to check potentially applicable technologies, the user first must identify the contaminants that require treatment. The guide then provides information that facilitates the selection of technologies that may apply to a site. This allows for the screening of the technologies early in the study of the site and the identification of data needs that should be considered in the scoping of the site sampling plan and site feasibility studies.

The contamination groups are listed horizontally across the top and the technologies are listed vertically down the left margin of each table. The waste groups in the tables are organized in a manner that reflects similar characteristics. Some of the technology included in this guide may be used only for volume reduction, waste separation and may not completely treat or destroy the constituents of the wastes. They have been included because they represent a major step in the overall management of a waste.

The following descriptors are used to characterize the technologies for each contamination group:

1. Demonstrated effectiveness: (symbol ). The technology has been used successfully on a commercial scale.

2. Potential effectiveness: (symbol $\Delta$ ). The technology has not been proven for specific CERCLA waste; however, it does have the characteristics needed for successful application.

3. No effectiveness: (symbol $\diamond$ ). The technology is not expected to remove or destroy the contaminant, but the contaminant does not interfere with the process.

4. Adverse impact: (symbol $X$ ). The contaminant interferes with or adversely impacts the environment.

The tables also present limitations and special use considerations for the particular treatment technology. The phase of development of the technology is also included in the table. The phases are:

1. Available technology: A technology that is fully proven and in commercial and private use.

2. Innovative technology: A technology for which cost or performance information is incomplete. It requires full-scale field testing before it is considered proven and available for use.

3. Emerging technology: A technology that has not yet passed laboratory or pilotscale testing.

The references are listed in the last column of each table to direct the reader to more detailed sources of information on the technology. 


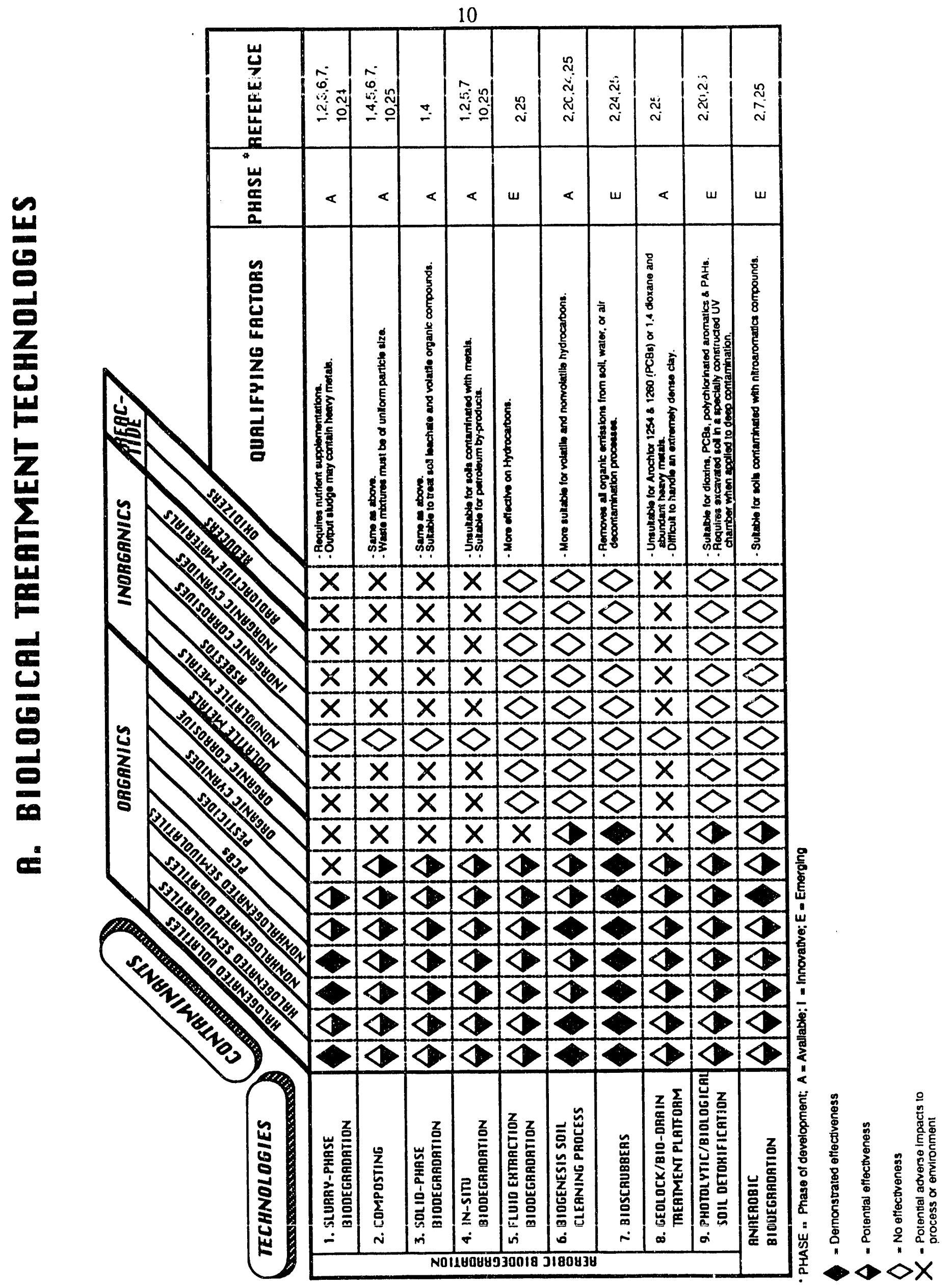


11
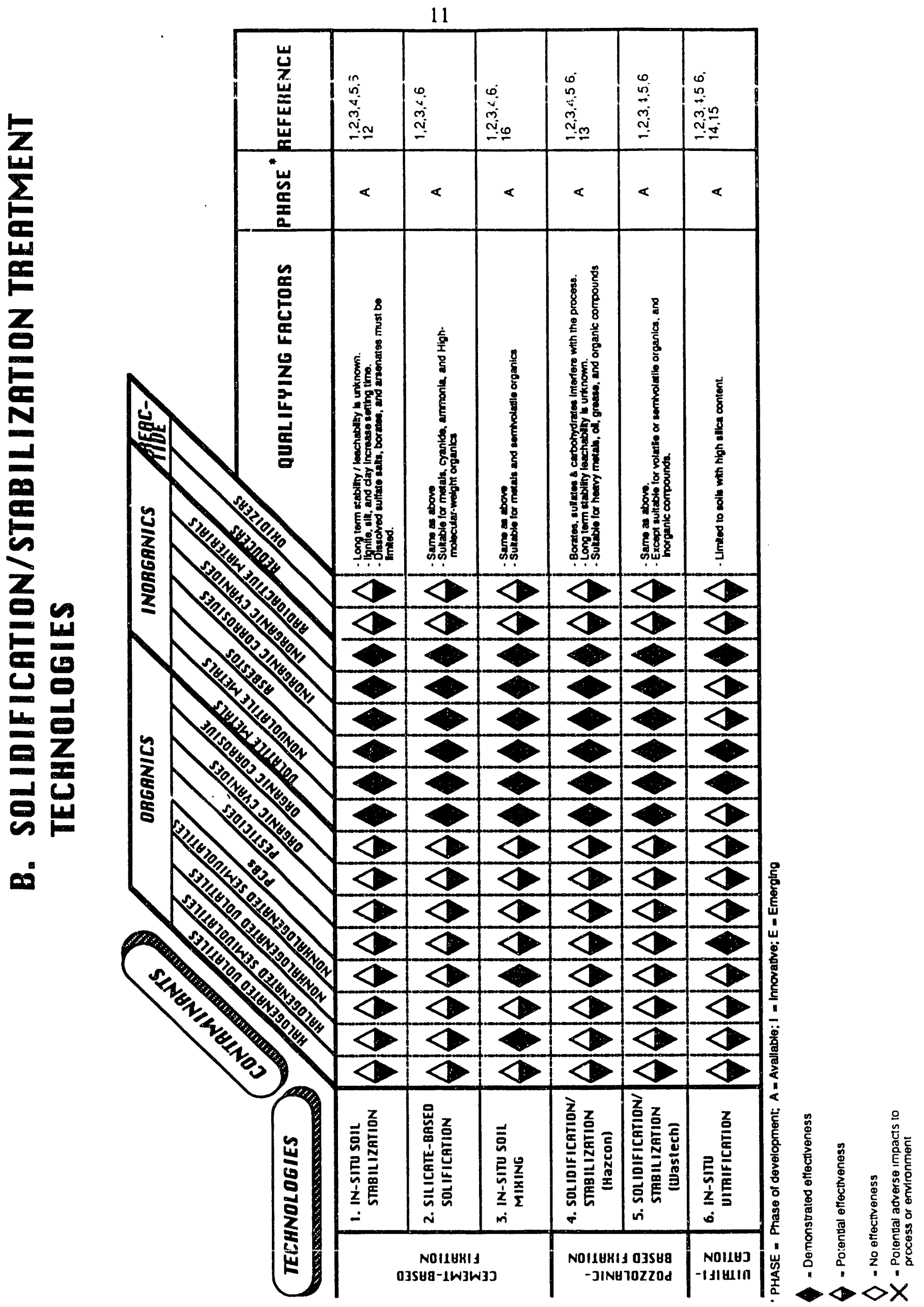


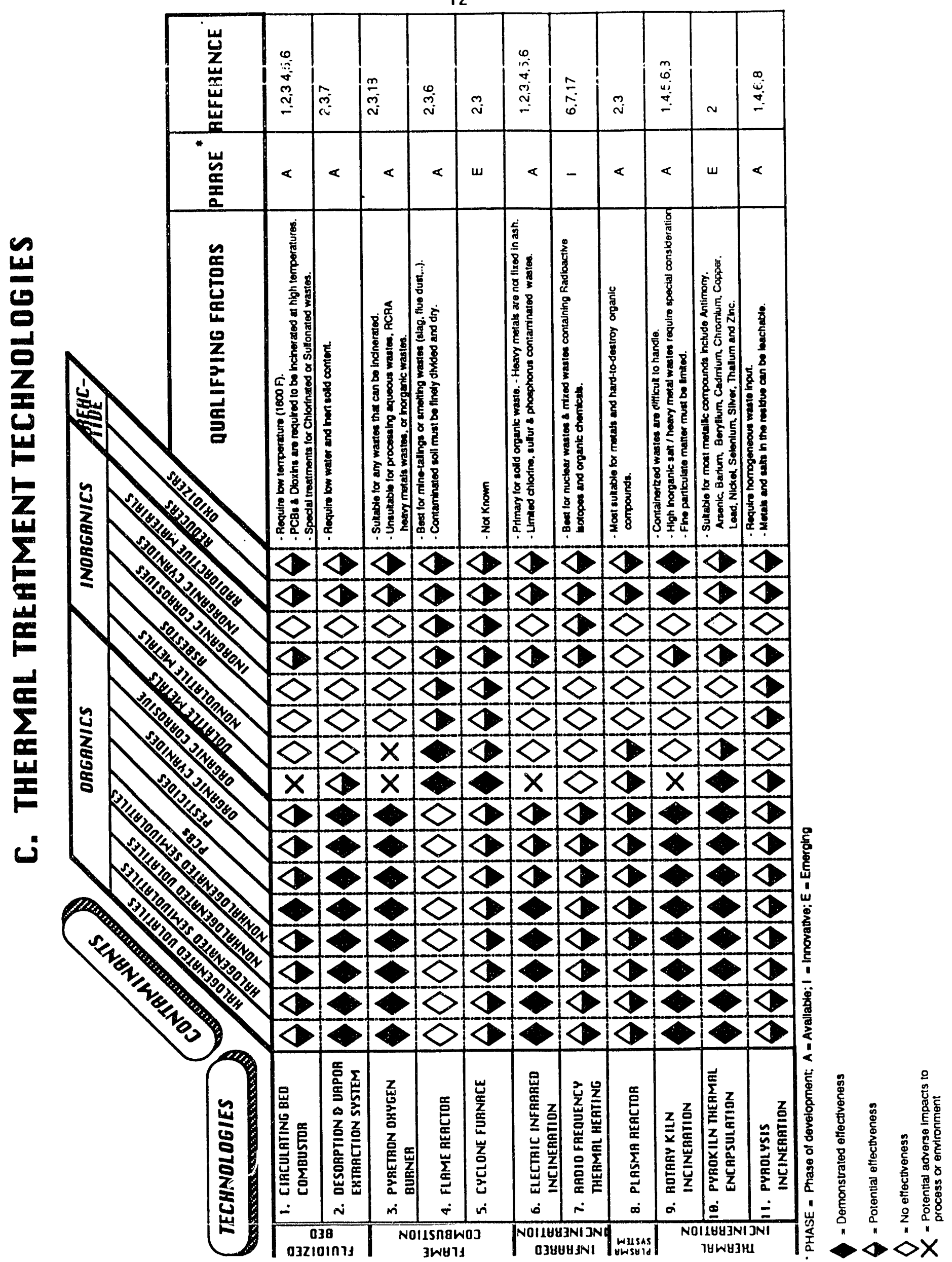




\begin{tabular}{|c|c|c|c|c|c|c|c|c|c|c|}
\hline 岕 & $\stackrel{m}{\stackrel{n}{\sim}}$ & 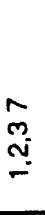 & $\begin{array}{l}\hat{n} \\
\stackrel{n}{n} \\
\underline{N}\end{array}$ & 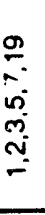 & $\stackrel{\stackrel{n}{m}}{\stackrel{\leftrightarrow}{=}}$ & 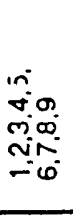 & $\sim$ & 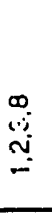 & 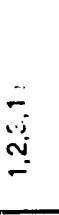 & $\stackrel{\sim}{\sim}$ \\
\hline 岕 & $\ll$ & $\ll$ & $w$ & $\ll$ & $\ll$ & $<$ & $\ll$ & $<$ & $\ll$ & $w$ \\
\hline
\end{tabular}

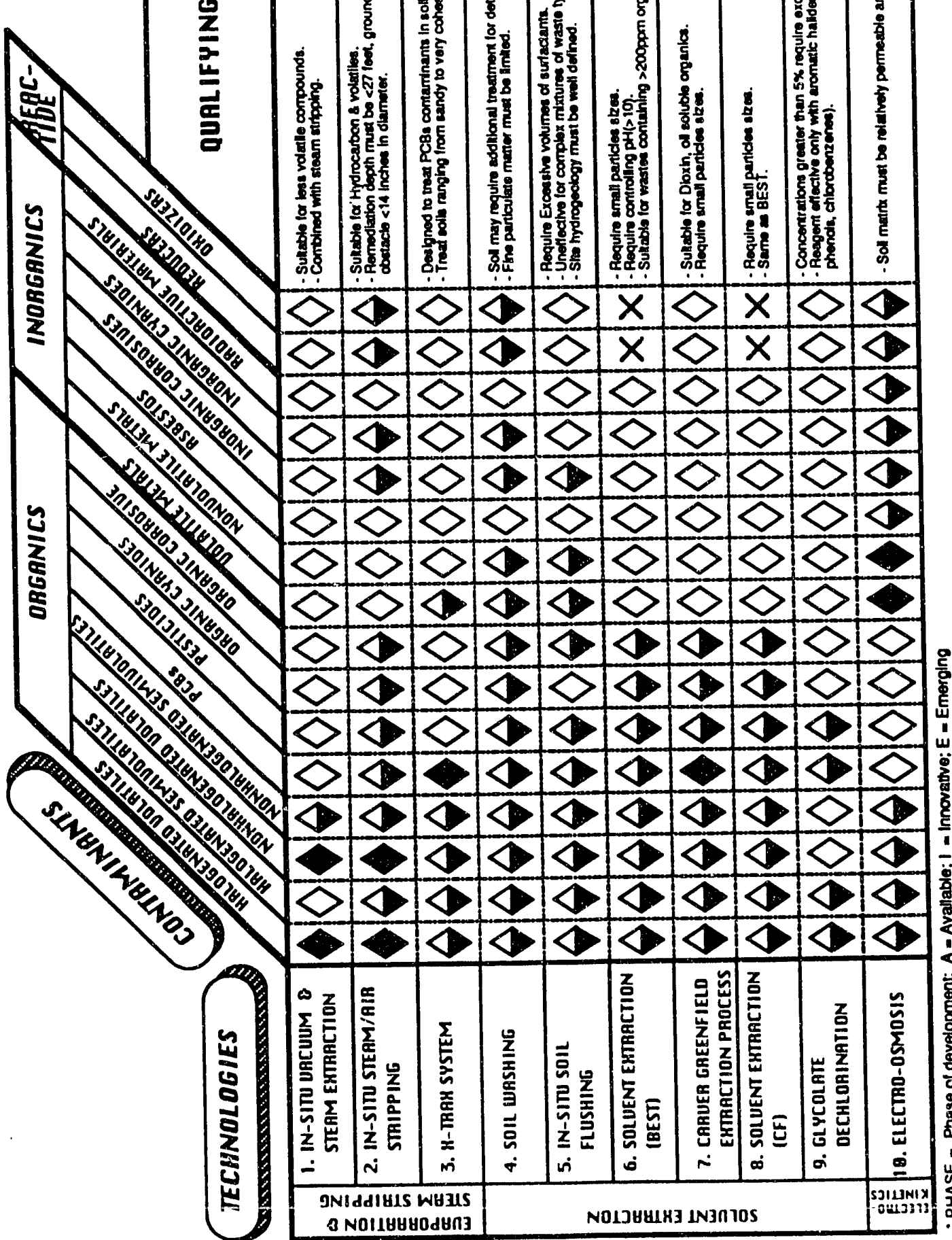




\section{IU. CONTAMINANT WASTE GROUPS}

HRL OGENATED UOLATILES

Bromodichloromethone

Bromoform

Bromemethane

Carbon tetrachloride

Chlorodibromomethane

Chlorobenzene

Chloroethane

Chloropropane

Dibromomethane

CIs,1,3-Dichloropropene

1,1-Dichloroethane

1,2-Dichloroethane

1,1-olchloroethene

1,2-oichloroethene

1,2-Dichloropropane

Fluorotrichloromethane

Me thylene chlorlde

1,1,2,2-tetrachloroethane

Tetrachloroethene

1,1,1-Trichloroethene

1,1,2-Trichioroethane

1,2-Trans-dichloropropene

Trens-1,3-dichloropropene

1,1,2-trichloro-1,2,2-trifluoroethane

Irichloroe thene

Uinyl chloride

Total chlorinated hydrocarbons

Нена chloroethone

Dichloromethone

\section{HALOGENATEO SEMIUOLRTILES}

2-chlorophenol

2,4-dichlorophenol

HeHachlorocyclopentedlene

p-chloro-m-cresol

Pentochlorophenal

Tetrachlorophenol

2,4,5-trichlorophenol

2,4,6-trichlorophenol

Bis-(2-chloroethohy)methane

Bis(2-chloroethyl)e ther

Bis(2-chlorolsopropyl)ether

4-bromophenyl phenyl ether

4-chtoroaniline

2-chloronapthalene

4-chlorophengl phenylether

1,2-dichlorobenzene

1,3-dichlorobenzene

1,4-dichlorobenzene

3,3-dichlorobenzldine

Hehochlorobenzen:

Heнachlorobutadiene

1,2,4-trichlorobenzene

Bis (2-chloroethohy)phthalate

Bis(2-chloroethory)ether

1,2-bis(2-chloroethory)e thane
NONHGLOGENATED UOLATILES

Acetone

Acroleln

Acrylonitrile

Benzene

2-Butonone

Corbon disulflde

Cycloheranone

Ethyl acetate

Ethyl ether

Ethy! benzene

2-heranone

Isobutenol

Methonol

Methyl Isobutyl ketone

4-methyl-2-pentenone

n-butyl alcohol

Styrene

Toluene

Trimethyl benzene

UInyl oce tote

Kylene

NONHALOEENATEO SEMIUOLATILES

Benzolc acid

Cresols

2,4-dirne thylphenol

2,4-dinitrophenol

2-methyiphenol

4-methylphenol

2-nitrophenol

4-nitrophenol

Phenol

Acenophthene

Acenapthylerie

Anthracene

Benzldine

Benzo(a)anthracene

Benzo(b)fluoranthene

Benzo(k)fluoranthene

Benzo(a)pyrene

Beizolghriperylene

Benzyl alcohol

Bis(2-ethylne Hyl)phthalate

Butyl benzyl phthalate

Chrysene

Dibenzofuran

Diethyl phthelate

Dimethyl phthalate

Di-n-butyl phthalate

4,6-dinitro-2-methylphenol

2,4-dinitrotoluene

2,6-dinltrotoluene

di-n-octyl phthalate

1,2-diphenyinydrazene

fluoronthene 
Iv. CONTAMINaNT WhSIE GROUPS (COn tinueú)

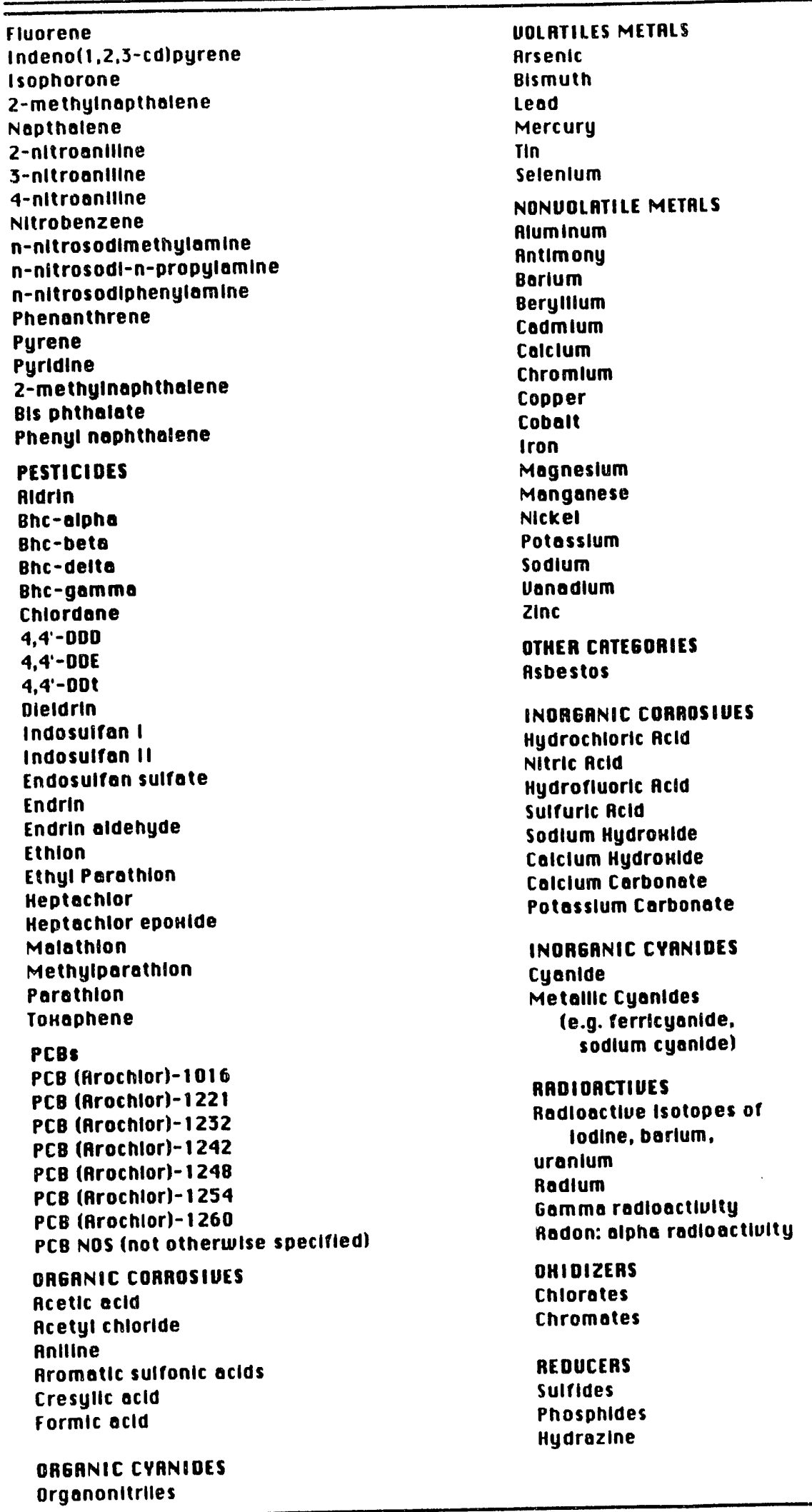




\section{v. RefERENCES}

1. Technology Screening Guide for Treatment of CERCLA Soils and Sludges; September 1988; EPA/540/2-88/004.

2. The Superfund Innovative Technology Evaluation Program (Technology Profile); November 1990; EPA/540/5-90/006.

3. The Superfund Innovative Technology Evaluation Program (Progress and Accomplishments Fiscal Year 1989); March 1990; EPA/540/5-90/001.

4. Superfund Treatability Clearinghouse Abstracts; August 1989; EPA/540/2-89/001.

5. Hand Book: Remediation of Contaminated Sediments; April 1991; EPA/625/6-91/028.

6. Guide to Treatment Technologies for Harzardous Wastes at Superfund Sites; March 1989; EPA/540/2-89/052.

7. A Comparison of the Effectiveness of Emerging In-Situ Technologies and Traditional Ex-Situ Treatment of Solvent Contaminated Soils; Engineering Science Inc.

8. Assessment of International Technologies for Superfund Applications; September 1988; EPA/540/2-88/003.

9. Innovative Technology: Best Solvent Extraction Process; November 1989; 9200.5-253FS.

10. Innovative Technology: Slurry-Phase Biodegradation; November 1989; 9200.5-252FS.

11. Innovative Techuiology: Glycolate Dehalogenation; November 1989; 9200.5-254FS.

12. Technology Evaluation Report: Site Program Demonstration Test International Waste Technologies In-Situ Stabilization/Solidification, Hialeah, Florida; June 1989; EPA/540/5-89/004a.

13. Application Analysis Report: Hazcon Solidification Process, Douglasville, Penn.; April 1990.

14. In-Situ Vitrification; 1990; Technology Transfer Bulletin.

15. In-Situ Vitrification Technology; January 23, 1992.

16. Soil Mixing for Insitu Stabilization; October 10, 1991; Memorandum number 91-0002. 

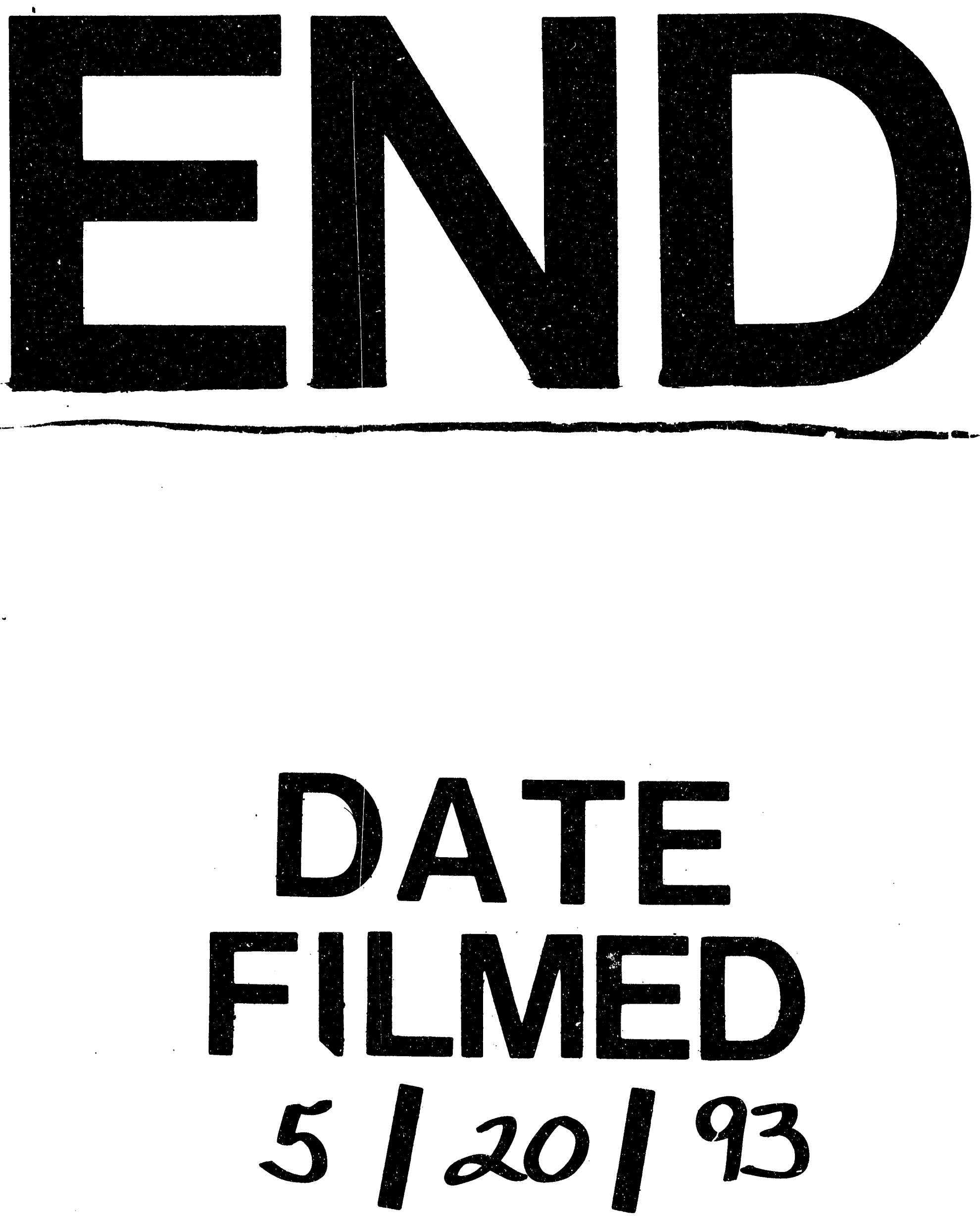
